\title{
The South China Sea Arbitral Award: legal implications for fisheries management and cooperation in the South China Sea
}

\author{
Yen Hoang Tran \\ Utrecht University, the Netherlands
}

This case note discusses the recent Award in the South China Sea arbitration and its implications for fisheries management and cooperation in the South China Sea. It argues that by rejecting the validity of the nine-dash line claim, clarifying the maritime entitlements of all the features in the Spratlys, and denouncing a number of Chinese activities in the South China Sea, the Award has remarkably contributed to narrowing the geographical scope of the disputes and thus defining the rights and obligations of States in different maritime areas. Ultimately, the Award has laid the foundation for future regional and bilateral efforts to cooperate, especially those of fisheries management and fisheries management cooperation in the South China Sea.

Keywords: South China Sea, arbitral award, fisheries management, fisheries cooperation

\section{INTRODUCTION}

On 12 July 2016, the Arbitral Tribunal under Annex VII of the 1982 United Nations Convention on the Law of the Sea (UNCLOS) ${ }^{1}$ issued its long-awaited award in the South China Sea arbitration initiated by the Philippines against China. ${ }^{2}$ The Award is historic and unprecedented in the sense that it officially rejected the validity of the nine-dash line claim, clarified the maritime entitlements of all the features in the Spratlys, and denounced a number of Chinese activities in the South China Sea. As a consequence, the scope of the South China Sea disputes is now significantly reduced and the respective rights and obligations of States are clearly defined. These significant developments are undeniably essential for any future regional or bilateral efforts to cooperate in the interests of peace, stability and prosperity in the region.

The South China Sea is a region of complex maritime and territorial disputes, resulting in escalating tensions among the claimants. Three main issues could be identified as the root of the disputes. First, States have long maintained conflicting claims over the land features in the Spratly Islands. Secondly, the nine-dash line claimed by China encircles most of the waters and features of the South China Sea, and China has increasingly conducted activities within the limits of the nine-dash line in order to reinforce its claim. Thirdly, the legal status of the features in the Spratly Islands remained

1. United Nations Convention on the Law of the Sea (adopted 10 December 1982, entered into force on 16 November 1994) 1833 UNTS 3 (UNCLOS).

2. The South China Sea Arbitration (The Republic of Philippines $v$ The People's Republic of China) (Award of 12 July 2016) <www.pcacases.com/web/sendAttach/2086> accessed 26 February 2017 (The South China Sea Arbitration). 
unclear, that is, whether they were rocks or islands under Article 121 of the UNCLOS. The uncertainty as to whether the features are capable of generating full or partial maritime entitlements has made it exceedingly difficult for States to negotiate on the management and settlement of the disputes.

One of the visible consequences of these long-standing disputes is the lack of coordinated fisheries regulations in disputed maritime areas, leading to constant conflicts at sea regarding fisheries activities between fishing vessels flagged to one of the claimants and the law enforcement agencies of another. Such disputes frequently make headlines across the world. ${ }^{3}$ Inevitably, this has led to a serious degradation of the fisheries resources in particular, and the marine environment in general in the region. According to a report by the Food and Agriculture Organization of the United Nations, most stocks in the West Central Pacific fishing area are either fully fished or overfished, particularly in the western part of the South China Sea. ${ }^{4}$ Another report by Sumaila and Cheung in 2015 also found that the fish stocks in the South China Sea have declined by $70-95 \%$ since the 1950 s..$^{5}$ It is imperative that immediate regional cooperative efforts should be made in order to manage and conserve the fisheries resources.

Against this background, section 2 of this paper begins by briefly discussing the main findings of the Arbitral Tribunal that are relevant to the issue of fisheries management and cooperation in the South China Sea. These findings include the validity of the nine-dash line, the legal status of the features in the Spratlys, and China's failure to exercise 'due diligence' with respect to its nationals and vessels and the marine environment. Section 3 elaborates on the possible implications that the award carries for future regional cooperative efforts in fisheries management and cooperation. Section 4 concludes with some ways forward.

\section{MERITS OF THE AWARD}

\section{1 (In)validity of the nine-dash line}

The Tribunal concluded that there was no legal basis for China to claim historic rights to resources within the sea areas falling within the 'nine-dash line' as this claim exceeded the geographic and substantive limits of China's maritime entitlements under the UNCLOS. ${ }^{6}$ The Tribunal explained that to the extent that China had historic rights to resources in the waters of the South China Sea, such rights were relinquished insofar as they were incompatible with the regime of the exclusive economic zone

3. See, for example, 'Vietnam Boat Sinks after Collision with Chinese Vessel' BBC (27 May 2014) <www.bbc.com/news/world-asia-27583564> accessed 26 February 2017; P Boykoff, 'Vietnam Fishermen on the Front Lines of South China Sea Fray' CNN (12 July 2016) <edition. cnn.com/2016/05/22/asia/vietnam-fisherman-south-china-sea/> accessed 26 February 2017.

4. Food and Agriculture Organization of the United Nations, 'The State of World Fisheries and Aquaculture 2016 - Contributing to Food Security and Nutrition for All' (2016) 44. See also R Bale, 'One of the World's Biggest Fisheries Is on the Verge of Collapse' National Geographic (29 August 2016) <www.news.nationalgeographic.com/2016/08/wildlife-southchina-sea-overfishing-threatens-collapse/> accessed 26 February 2017.

5. UR Sumaila and WWL Cheung, 'Boom or Bust - the Future of Fish in the South China Sea' (University of British Columbia, 2015) 2 <www.drive.google.com/file/d/0B_oUJE4kCTZrbVI4 N2tTVjlpYTA/view> accessed 26 February 2017.

6. $\quad$ The South China Sea Arbitration (n 2) [278]. 
(EEZ) provided for in the UNCLOS. ${ }^{7}$ It should be noted, however, that traditional fishing rights are not totally excluded within the EEZ regime. The coastal States, in giving access to fisheries resources to other States within its EEZ, 'shall take into account (...) the need to minimize economic dislocation in States whose nationals have habitually fished in the zone'. ${ }^{8}$ That being said, the Tribunal emphasised that 'States may continue to recognize traditional fishing rights in the exclusive economic zone in their legislation, in bilateral fisheries access agreements, or through regional fisheries management organizations. ${ }^{9}$

\subsection{Legal status of the features in the Spratlys}

After clarifying the interpretation and application of paragraph 3 of Article 121, the Tribunal concluded that none of the features in the Spratly Islands generated entitlements to an EEZ or continental shelf (CS). ${ }^{10}$ Even though the features had been heavily modified by land reclamation and construction activities, the Tribunal only considered:

historical evidence of conditions on the features prior to the advent of the exclusive economic zone as a concept or the beginning of significant human modification-to represent a more reliable guide to the capacity of the features to sustain human habitation or economic life. ${ }^{11}$

This implies that the current land reclamation and construction conducted by the parties will have no implication whatsoever for the qualification of the maritime entitlements of the features under Article 121 of the UNCLOS.

\subsection{Obligation of 'due diligence'}

The Tribunal also concluded that China failed to exercise 'due diligence' in preventing its nationals from unlawfully fishing in the EEZ of another State, and thus breached its obligation to pay 'due regard' to the rights and interests of that State under Article 58(3) of the UNCLOS. Here, the Tribunal adopted the conclusion in the Advisory Opinion of the International Tribunal for the Law of the Sea (ITLOS), issued in 2015 at the request of the Sub-Regional Fisheries Commission ${ }^{12}$ (Advisory Opinion to the SRFC), that the obligation of due regard extended to a duty 'to take the necessary measures to ensure that their nationals and vessels flying their flag are not engaged in IUU [Illegal, Unreported, and Unregulated] fishing activities'. ${ }^{13}$ This obligation, according to the Advisory Opinion, denotes an obligation of conduct, or a 'due diligence' obligation. ${ }^{14}$

The Tribunal could easily establish a violation on the part of China as 'the Chinese Government vessels were fully aware of the actions being taken by Chinese fishermen and were able to halt them had they chosen to do so'. ${ }^{15}$ This lack of 'due diligence'

7. Ibid [271].

8. UNCLOS (n 1) art 62(3).

9. The South China Sea Arbitration (n 2) [804(b)].

10. Ibid [646].

11. Ibid [578].

12. Request for Advisory Opinion submitted by the Sub-Regional Fisheries Commission (SRFC) (Advisory Opinion, 2 April 2015) ITLOS Rep 2015 (Advisory Opinion to the SRFC).

13. The South China Sea Arbitration (n 2) [743].

14. Advisory Opinion to the SRFC (n 12) [129].

15. The South China Sea Arbitration (n 2) [755]. 
was also addressed in the context of China's harmful fishing practices that violated the obligation to preserve and protect the marine environment under Article 192 of the UNCLOS. The condemned harmful fishing practices undertaken by Chinese nationals included the harvesting of endangered species, the consequential destruction of their habitat, ${ }^{16}$ and the use of cyanide and dynamite. However, the lack of sufficient evidence regarding the use of explosives and cyanide did not allow the Tribunal to conclude that China had failed to take measures to prevent such practices. ${ }^{17}$

\section{LEGAL IMPLICATIONS FOR FISHERIES MANAGEMENT AND COOPERATION IN THE SOUTH CHINA SEA}

\subsection{Clarifying the geographical scope of the disputes}

For a long time, various cooperative proposals have been put forward, such as the establishment of a joint development area, in order to manage the conflicts as well as to pursue economic development of the South China Sea. ${ }^{18}$ However, one of the practical obstacles for such proposals is the definition of the disputed areas. ${ }^{19}$ As the Tribunal invalidated the nine-dash line claim and declined to qualify the features in the Spratlys as islands with full maritime entitlements, there would neither be an overlap between the coastal States' EEZ claims and the Chinese claim, nor an overlap between the coastal States' EEZ claims and the maritime zones generated from the disputed features in the Spratlys. As a result, the disputed areas now include only those in which EEZ/CS claims from the mainland of the parties overlap - for instance, between Indonesia and Vietnam, or between China and Vietnam beyond the Gulf of Tonkin and the territorial seas surrounding the disputed features.

It is clear that a great portion of that previously claimed as disputed areas has now become the high seas. However, the question as to whether the Area exists in the centre of the South China Sea remains uncertain as this depends on the submissions by the coastal States of the CS beyond 200nm and the recommendations by the Commission on the Limits of the Continental Shelf.

\subsection{Clarifying legal rights and obligations of the States concerned in the relevant areas of the South China Sea}

As the Tribunal remarked, 'the purpose of dispute resolution proceedings is to clarify the Parties' respective rights and obligations and thereby to facilitate their future relations' ${ }^{20}$ Accordingly, the seminal South China Sea Award has helped clarify the rights and obligations of the States concerned in different maritime areas in the South China Sea, especially with regard to fisheries management and cooperation.

16. Ibid [950]-[66].

17. Ibid [975].

18. See, for example, K-H Wang, 'Bridge over Troubled Waters: Fisheries Cooperation as a Resolution to the South China Sea Conflicts' (2001) 14(4) The Pacific Review 531; L Bernard, 'Prospect for Joint Development in the South China Sea' (Managing Tensions in the South China Sea Conference, Washington DC, 5-6 June 2013).

19. Z Keyuan, 'Joint Development in the South China Sea: A New Approach' (2006) 21(1)

The International Journal of Marine and Coastal Law 83, 102.

20. The South China Sea Arbitration (n 2) [1198]. 
Within the EEZ, States are entitled to exercise their sovereign rights for the purposes of exploring and exploiting, conserving and managing living and non-living natural resources in the waters superjacent to the seabed and in the seabed and its subsoil, and with regard to other activities for the economic exploitation and exploration of the zone. ${ }^{21}$ It follows that coastal States have the sole discretion as regards the conservation and utilisation of living resources under Articles 61 and 62 of the UNCLOS. States whose nationals have habitually fished in the EEZ may have access to the fisheries resources only with prior consent from the coastal States. Currently, in the South China Sea, the only fisheries agreement of this type was concluded between China and Vietnam in the Gulf of Tonkin in 2000, ${ }^{22}$ according to which the two parties have established a joint fishing zone to which both Chinese and Vietnamese fishermen are granted equal access. This fisheries agreement sets a good example for bordering States to follow, and similar agreements can be concluded between States to provide fishermen from one State with access to surplus fisheries resources in the EEZ of another.

Also, as the South China Sea is the habitat of a great number of straddling and highly migratory stocks, the States concerned are under the obligation to cooperate either directly or through appropriate sub-regional or regional organisations, as regards the conservation and development of such stocks. ${ }^{23}$ For shared stocks - those migrating between the EEZs of more than one State - and straddling stocks - those migrating between the EEZs and the high seas, States are only subjected to a pactum de negotiando, ${ }^{24}$ meaning the obligation to negotiate in good faith. For the highly migratory stocks, coastal States are further subjected to a pactum de contrahendo, ${ }^{25}$ which requires the States to reach a cooperation agreement as an end result. ${ }^{26}$ The rights and obligations of States with regard to these stocks have been discussed extensively by the ITLOS in its Advisory Opinion to the SRFC.

Within the areas of overlapping EEZ/CS claims, Articles 74 and 83, paragraph 3 stipulate two distinctive procedural obligations of conduct, including the obligation to make every effort to reach provisional arrangements of a practical nature, and the obligation to make every effort not to jeopardise or hamper the reaching of a final agreement. These two obligations have been addressed by the Arbitral Tribunal in the maritime delimitation case between Guyana and Suriname in 2007 in the context of the exploration and exploitation of hydrocarbon resources. ${ }^{27}$ In this case, the Tribunal emphasised that compliance with the two obligations was crucial for the

21. UNCLOS (n 1) art 56(1)(a).

22. Agreement between the People's Republic of China and the Socialist Republic of Viet Nam on the Delimitation of the Territorial Seas, Exclusive Economic Zones and Continental Shelves of the Two Countries in Beibu Gulf/Bac Bo Gulf (concluded 25 December 2000, entered into force 30 June 2004) 2336 UNTS 179; see NH Thao, 'Maritime Delimitation and Fishery Cooperation in the Tonkin Gulf' (2005) 36(1) Ocean Development and International Law 25, 41-4.

23. UNCLOS (n 1) arts 63, 64.

24. Ibid art 63.

25. Ibid art 64 .

26. For the distinction between pactum de negotiando and pactum de contrahendo, see H Owada 'Pactum de Contrahendo, Pactum de Negotiando', Max Planck Encyclopedia of Public International Law (OUP, Oxford 2012) Vol VIII, 18.

27. Maritime Delimitation (Guyana v Suriname) (Jurisdiction and Merits, Award of 17 September 2007) (2008) 47 ILM 224. 
achievement of certain objectives of the UNCLOS, namely to promote the equitable and efficient utilisation of resources of the seas and oceans, to strengthen peace and friendly relations between nations, and to peacefully settle disputes. ${ }^{28}$ In order to fulfil the first obligation, States are free to choose the temporal and geographical scope as well as the types of the provisional arrangements, but these provisional arrangements in any case shall not prejudice the final conclusion of a maritime delimitation agreement. ${ }^{29}$ At the same time, States are required to make every effort not to jeopardise or hamper the reaching of a final agreement. For instance, coastal States are not allowed to authorise the over-exploitation or depletion of fisheries resources in the overlapping areas, ${ }^{30}$ nor to enforce rules and regulations against the vessels flagged to the other claimant State if the situation does not so require. So far, provisional fisheries arrangements pending the final maritime delimitation have been concluded between Malaysia and Indonesia in 2012, ${ }^{31}$ and between the Philippines and Taiwan in 2015. ${ }^{32}$ Both of these arrangements deal with fisheries law enforcement cooperation in unresolved maritime areas between these parties.

Within the disputed territorial seas around the disputed features, as opposed to the EEZ regime, the Tribunal ruled that historic fishing rights were to be preserved within the territorial seas. ${ }^{33}$ Even though the Tribunal has left open the question of the limits of the historic fishing rights, China's complete prevention of the Philippines' fishermen from fishing in this area, while permitting its own nationals to do so, was sufficient for the Tribunal to conclude a violation on the part of China. It can thus be suggested that States in control of the disputed features would be under the obligation to respect the historic fishing rights of other claimant States in the territorial seas of the disputed features, and any conservation measures to be taken must be applied on a non-discriminatory basis.

On the high seas, all States are entitled to exercise the freedom of high seas as provided by Article 87 of the UNCLOS, including, inter alia, the freedom of fishing. While exercising its freedom of fishing on the high seas, States have a duty to adopt, with respect to their nationals, measures for the conservation of the living resources of the high seas and to cooperate with other States in the conservation and management of such resources under Article 117. For the conservation of the same living resources or different resources in the same area, under Article 118, States are subject to a pactum de negotiando as regards necessary measures to conserve those resources, and are under the obligation, as appropriate, to cooperate to establish sub-regional or regional fisheries organisations to this end. As the high seas in the South China Sea do not currently fall

28. Ibid [460], [465].

29. Ibid [460]-[64]. See also D Anderson and Y van Logchem, 'Rights and Obligations in Areas of Overlapping Maritime Claims' in S Jayakumar, T Koch and R Beckman (eds), The South China Sea Disputes and Law of the Sea (Edward Elgar, Cheltenham 2014) 192.

30. Anderson and van Logchem (n 29) 218-19.

31. Memorandum of Understanding between the Government of the Republic of Indonesia and the Government of Malaysia in respect of the Common Guidelines concerning Treatment of Fishermen by Maritime Law Enforcement Agencies of Malaysia and the Republic of Indonesia (concluded 27 January 2012) <www.treaty.kemlu.go.id/uploads-pub/1273_MYS2012-0127.pdf $>$ accessed 26 February 2017.

32. The Agreement Concerning the Facilitation of Cooperation on Law Enforcement in Fisheries Matters between the Taipei Economic and Cultural Office in the Philippines and the Manila Economic and Cultural Office in Taiwan (concluded 5 November 2015, entered into force 5 December 2015) on file with the author.

33. The South China Sea Arbitration (n 2) [804(c)]. 
within the competence of any regional fisheries management organisations, ${ }^{34}$ it is vital that the States concerned negotiate and cooperate to establish a regional mechanism for the conservation and management of fisheries resources in the high seas area.

In any case, the South China Sea is a semi-enclosed sea, and thus Article 123 requires the bordering States to endeavour, directly or through an appropriate regional organisation, to coordinate the management, conservation, exploration and exploitation of the living resources of the sea. Again, this obligation does not require a cooperation agreement be concluded and States are only required to negotiate in good faith.

\subsection{Confirming the application of the obligation of 'due diligence' of flag States with respect to their fishing vessels and the marine environment}

Before any cooperative regime is established among the States, the Tribunal's finding of a violation of Article 58(3) of the UNCLOS by China confirms that the flag State is under a 'due diligence' obligation to ensure that its fishing vessels do not unlawfully fish within the EEZ of the coastal States. First, the flag State must ensure that its fishermen do not fish within the EEZ of another State, where it does not have permission to fish. This, again, proves the pressing need for consultation with the coastal States to gain consent for granting access to the surplus of the fisheries resources in its EEZ. Secondly, when fishing within the EEZ of coastal States, flag States must ensure that their fishermen have due regard to the rights and duties of the coastal States and comply with the laws and regulations adopted by such States. This requires the two States to frequently exchange information as to the fisheries law and regulations applicable in the area concerned. Moreover, flag States are also under a 'due diligence' obligation to ensure that their fishing practices do not have harmful impacts on the marine environment.

In addition to the willingness of the States, it is admitted that a common practical problem that most of the States in the South China Sea face is the lack of law enforcement capacity to fulfil their obligation as flag States. ${ }^{35}$ Even in China, which can be said to possess the best-equipped and modern law enforcement vessels, the staff and equipment for enforcement of the fishery regulations are insufficient, and thus the law enforcement has not achieved good results. ${ }^{36}$ In this case, it is encouraged that bordering States reflect upon the bilateral and multilateral collaborative initiatives that have been taken among several States in the region in order to foster the capacitybuilding process and improve the effectiveness and efficiency of fisheries law enforcement at sea. ${ }^{37}$

34. The most relevant regional fisheries management organisation in the present context is the West Central Pacific Fisheries Commission, but this Commission clearly states that its convention area is understood not to include the South China Sea in practice. See West Central Pacific Fisheries Commission, 'Frequently Asked Questions and Brochures' <www.wcpfc.int/ frequently-asked-questions-and-brochures> accessed 26 February 2017.

35. Sumaila and Cheung (n 5) 18. In the context of IUU fishing in South East Asia, see ASEAN-SEAFDEC, ASEAN Guidelines for Preventing the Entry of Fish and Fishery Products from IUU Fishing Activities into the Supply Chain (SEAFDEC, 2015) $6<\mathrm{www}$. asean.org/storage/images/2015/November/AMAF/App\%209\%20-\%20ASEAN\%20Guidelines \%20IUU\%20SSOM36th\%20AMAF\%20final.pdf> accessed 26 February 2017.

36. G Shen and M Heino, 'An Overview of Marine Fisheries Management in China' (2014) 44 Marine Policy 265, 270.

37. ASEAN Guidelines (n 35) 13-14. 


\section{WAYS FORWARD}

As the South China Sea fisheries resources are on the brink of collapse, it is time that all States concerned in the region set aside their sovereignty claims over the features and work together towards a multilateral agreement on fisheries management. Pending the conclusion of any regional solution, it is required that States recognise and comply with the Award by respecting the sovereignty, as well as the sovereign rights and jurisdiction, of other States within their maritime zones. Most importantly, States are under an obligation, either directly or through a regional and sub-regional fisheries organisation and arrangement, to cooperate to manage fisheries resources shared between their EEZs, or straddling the EEZ and the high seas, especially the highly migratory stocks.

With the nine-dash line claim invalidated and the status of the features in the Spratlys clarified, it will now be much easier for the States to define the scope of the cooperation areas. These potential cooperation areas may cover only the remaining disputed areas, which are the overlapping EEZs between States, or the disputed territorial seas around the disputed features in the Spratlys. Ideally, for the sake of fisheries resources, the determination of the areas of cooperation should follow the biological features as well as the straddling patterns of the fish stocks, which merit further special analytic attention. 